\title{
Social, psychological and demographic variables related to breast- feeding among Kuwaiti mothers
}

Yagoub Al-Kandari ${ }^{1}$ and Ramadan A. Ahmed ${ }^{2}$

${ }^{1}$ Department of Sociology and Social Work and Anthropology, Kuwait University, Kuwait (Correspondence to: Y.Y. Al-Kandari: alkandari66@hotmail. com). ${ }^{2}$ Department of Psychology, Munofiya University, Egypt.

\begin{abstract}
Background: Many studies have discussed the relationship between breastfeeding and certain social, psychological and demographic variables.

Aims: The aim of this study was to determine the effect of social, psychological and demographic variables on breastfeeding among Kuwaiti mothers.

Methods: The total of 712 married women were selected who answered a questionnaire. Questions were asked about duration of breastfeeding and bottle feeding, degree of spousal relationship, religious sect and background. Religiosity, family stability and general health self-rating scales were used.

Results: Women who came from urban roots and consanguineous marriages had a higher mean duration of breastfeeding than those who came from Bedouin roots and nonconsanguineous marriages. There was a significant difference among the three maternal age groups in the duration of breastfeeding. A significant relationship was found between the duration of breastfeeding and all social, psychological and demographic variables except general health. Correlations were found between the duration of breastfeeding and maternal and paternal education, maternal occupation, years of marriage, age at marriage, family stability scale, self-esteem scale, and socioeconomic variables. The duration of artificial feeding, number of abortions, degree of religiosity, family stability scale, age, and socioeconomic scale related to the duration of the mother's breastfeeding.
\end{abstract}

Conclusions: Education plays an important role in affecting women's health in general and breastfeeding practice in particular.

Keywords: breastfeeding, artificial feeding, social factors, psychological factors, demographic factors.

Citation: Al-Kandari Y; Ahmed RA. Social, psychological and demographic variables related to breastfeeding among Kuwaiti mothers East Mediterr Health J. 2018;24(7):624-630. https://doi.org/10.26719/2018.24.7.624

Received:12/11/15; accepted: 26/07/17

Copyright (C) World Health Organization (WHO) 2018. Some rights reserved. This work is available under the CC BY-NC-SA 3.o IGO license (https:// creativecommons.org/licenses/by-nc-sa/3.o/igo)..

\section{Introduction}

Few studies have dealt with breastfeeding behaviour in Kuwait. Al-Enezi et al. concluded that there is a range of economic, social and educational factors associated with reproductive behaviour, breastfeeding and child nutrition (1). One study from the 1970s compared children's feeding and parental attitudes towards children's food in Kuwait, Egypt and Bahrain, with a focus on the transition from breastfeeding to regular food (2). Variables examined included maternal nutrition and education, parental age, monthly income, and age of the children when they were weaned. There was a significant relationship between these variables and children's feeding behaviour. Another study concentrated on breastfeeding versus artificial feeding and weaning behaviour of 2833 Kuwaiti mothers with children aged $\leq 1$ year (3). The researchers found that $>60 \%$ of mothers breastfed their children on an average of 5.8 months. Differences in breastfeeding duration were found between old and young mothers. They also found that most infants in families without nursemaids were breastfed by their mothers. Al-Bustan and Kohli found a relationship between some socioeconomic variables and breastfeeding, including a lower rate of breastfeeding among working mothers (4). Fluoride was found more often in the teeth of children who were breastfed compared with those who were not.

Studies about breastfeeding behaviour conducted in the last two or three decades of the last century in Kuwait have revealed significant changes due to the effects of modern life. For example, the increase in the number of women obtaining a higher education and being involved in the workplace changed the role and status of women in contemporary Kuwaiti society (5). In 2006, the numbers of women participating in the Kuwaiti labour force reached the highest rate in the Arab world, increasing from $37 \%$ in 2003 to $42 \%$ (6). These statistics leave no doubt about the significant impact of a woman's career on the length of time she chooses to breastfeed and on her behavior toward her child in general because of the impact of her absence from home when compared to the traditional stay-at-home mothers. These studies did not consider the relationship between some of the social and psychological variables and maternal breastfeeding behaviour, such as the cultural differences between social groups within a community. 
The aim of the current study was to determine the effect of social, physiological and demographic variables on breastfeeding among Kuwaiti mothers. The study was based on the following hypotheses: 1) there are significant differences between Sunni and Shiite, urban and Bedouin, and consanguineous and nonconsanguineous marriages in breastfeeding and artificial-feeding behaviour; 2) there are significant differences among women's age and breastfeeding duration for the first four children that women bear; and 3) there is a significant relationship between some sociocultural, demographic and psychological factors and breast- or bottle-feeding behaviour.

\section{Methods}

\section{Study sample}

A total of 712 married Kuwaiti women, aged 17-61 years, were selected from the six governorates in Kuwait using a nonrandom opportunistic voluntary sampling method during 2013. Research assistants helped to collect data by direct contact with the participants and the response rate was high. Only a few questionnaires were omitted, due to the fact that they were not completed in full. The respondents answered the questionnaire voluntarily after an explanation of the study aims. The method of sample selection and some of the study tools and variables were used in similar studies conducted elsewhere (7-10). Respondents were informed that the researchers would respect their confidentiality and anonymity. They were also informed that participation in this study was voluntarily. Informed consent was obtained.

\section{Variables and measurements}

The questionnaire included demographic information about paternal education, maternal occupation, maternal age, governorates and family income. Other family and social variables included: years of marriage, age at marriage, number of children, number of abortions, and average year of discontinuing breastfeeding. Education was divided into eight categories, from 1 "read and write or below" to 8 "PhD". Annual family income was also divided into eight categories, from 1 " $\leq 500$ Kuwaiti dinars" to 8 " $\geq 2100$ Kuwaiti dinars". Occupation was divided into six categories, from 1 "not working (housewife)" to 6 "professional". Socioeconomic status was measured by using three variables: annual income, educational level, and occupational position coded according to the Social Science Research Council.

Respondents were asked about the duration of breastfeeding and using artificial feeding. Respondents were asked for how long they breastfed their infants and when they started artificial feeding. There were also questions about consanguineous/nonconsanguineous marriage, Sunni or Shiite religious sect, and tribal or urban origins.

The self-rating scale of religiosity was measured by the following question: "What is your level of religiosity in general?" and the self-rating scale of general health question was, "What is your estimation of your health in general?" A scale from o to 10 was used. The respondents were asked to circle the number to describe their feelings concerning their religiosity and health. For religiosity, the lowest score (o) was "not religious at all," and the highest score was "very religious." For health, the lowest score (o) was "feeling poorly," and the highest score was "feeling excellent". These 2 single item self-reports have been used previously for research in Kuwait $(11,12)$. Both scales show reliability and validity. For example, the self-report scale for religiosity shows temporal stability and both concurrent and factorial validity (13). AbelKhalek reported, "Although there are Western-developed inventories to measure religiosity, they are based on the Christian concept of God. It is not yet known whether these inventories are valid for Islamic conceptions" (12). A 1-week test-retest of reliability for these 2 scales was completed, which showed a correlation of 0.77 and 0.89 for the 2 scales, respectively.

Some social and psychological scales were also used. The family stability scale developed by Muktar contained 31 sentences, to which the participants responded using a 5-point scale: from strongly agree (5) to strongly disagree (1) (6). The Self-Esteem scale developed by Rosenberg was used in this study (14). The scale contained 10 sentences, with a 5-point scale from strongly agree (5) to strongly disagree (1). The emotional scale developed by Darweesh and Shaker, which was used in a Jordanian study, was used with some modifications to fit the sample in the current study (15). The overall scale contained 35 sentences, to which the participants responded using a 5-point scale: from strongly agree (5) to strongly disagree (1). Six faculty members from the College of Social Sciences reviewed the scales to obtain content validity. For reliability, these scales have been shown to have high internal consistency overall ( $\alpha$ coefficient of 0.94, 0.77 and 0.95, respectively).

\section{Statistical analysis}

SPSS version 19.0 was used for data analysis. Both descriptive and inferential statistics were used to examine the research hypotheses. The $t$-test was used to examine differences between Sunni and Shiite, urban and Bedouin, and consanguineous and nonconsanguineous marriages with regard to breastfeeding and artificial feeding. Analysis of variance was used to examine differences among three age groups of mothers in relation to breastfeeding. Correlation coefficients between breastfeeding and artificial feeding with some sociocultural, demographic and physiological factors were used. For the purpose of predicting breastfeeding and artificial feeding times, a multiple linear regression model was used.

\section{Results}

There was no significant difference between Sunnis and Shiites concerning duration of breastfeeding or artificial feeding (Table 1). There was no significant difference between urban and Bedouin mothers concerning duration of breastfeeding. However, women of urban origin had a significantly higher mean duration of 


\begin{tabular}{|c|c|c|c|c|c|c|c|c|c|c|}
\hline \multirow[t]{2}{*}{ Variables } & \multicolumn{6}{|c|}{ Breastfeeding $^{\mathrm{a}}$} & \multicolumn{4}{|c|}{ Artificial feeding ${ }^{a}$} \\
\hline & $\mathbf{n}$ & $\mathbf{M}$ & SD & $t$ & $\mathbf{P}$ & $\mathbf{n}$ & $\mathbf{M}$ & SD & $t$ & $\boldsymbol{P}$ \\
\hline $\begin{array}{l}\text { Sect } \\
\text { Sunni } \\
\text { Shiite }\end{array}$ & $\begin{array}{l}462 \\
136\end{array}$ & $\begin{array}{c}6.55 \\
6.0\end{array}$ & $\begin{array}{l}6.69 \\
6.62\end{array}$ & 0.847 & NS & $\begin{array}{l}447 \\
141\end{array}$ & $\begin{array}{l}20.65 \\
19.35\end{array}$ & $\begin{array}{c}10.04 \\
11.79\end{array}$ & 1.29 & NS \\
\hline $\begin{array}{l}\text { Roots } \\
\text { Urban } \\
\text { Bedouin }\end{array}$ & $\begin{array}{l}167 \\
422\end{array}$ & $\begin{array}{l}6.29 \\
6.52\end{array}$ & $\begin{array}{l}7.14 \\
6.54\end{array}$ & -0.385 & NS & $\begin{array}{l}171 \\
406\end{array}$ & $\begin{array}{l}21.43 \\
19.61\end{array}$ & $\begin{array}{c}9.67 \\
10.81\end{array}$ & 2.43 & $<0.05$ \\
\hline $\begin{array}{l}\text { Spousal relationship } \\
\text { Consanguineous } \\
\text { Nonconsanguineous }\end{array}$ & $\begin{array}{l}246 \\
344\end{array}$ & $\begin{array}{l}7.46 \\
5.76\end{array}$ & $\begin{array}{l}7.39 \\
6.09\end{array}$ & 3.04 & $<0.01$ & $\begin{array}{l}239 \\
343\end{array}$ & $\begin{array}{l}20.36 \\
20.49\end{array}$ & $\begin{array}{l}10.29 \\
10.56\end{array}$ & 0.156 & NS \\
\hline
\end{tabular}

aSome mothers used both artificial feeding and breastfeeding.

$M=$ mean; $S D=$ standard deviation; $N S=$ not significant.

artificial feeding than those of Bedouin origin. Women in a consanguineous marriage had a significantly higher mean duration of breastfeeding than women in a nonconsanguineous marriage.

Maternal age is an important determinant of breastfeeding. We investigated the differences among age groups in breastfeeding the first four children (Table 2). For the first child, there was a significant difference among the three age groups in the duration of breastfeeding. The highest mean duration was found among women aged $\geq 41$ years, while the lowest duration was in women aged $31-40$ years. Women aged $\geq 41$ years had a higher mean duration of breastfeeding for their second, third and fourth children, while those aged $\leq$ 30 years had a lower mean duration of breastfeeding. In general, older women breastfeed their children for a longer time than younger women do. Table 2 shows that the longest mean durations were found among women aged $\geq 41$ years for breastfeeding their children compared with the other age categories. A t-test showed that there was a significant difference between the overall mean of breastfeeding the fourth child versus the first child $(P<$ 0.001).

There were significant relationships between the duration of breastfeeding and all social, psychological and demographic variables, except average year of stopping breastfeeding and general health (Table 3). Negative significant correlations were found between the duration of breastfeeding and maternal and paternal education, maternal occupation, maternal years of marriage, maternal age at marriage, family stability scale, self-esteem scale and socioeconomics. In contrast, positive correlations were found between duration of breastfeeding and number of children, number of abortions, age, and religiosity and emotional scales.

There was a positive relationship between duration of artificial feeding and maternal occupation, years of marriage, family stability and self-esteem scales, and socioeconomics. In contrast, negative correlations were found between artificial feeding duration and number of abortions, maternal age and religiosity.
To predict the effect of social, psychological and demographic variables on the duration of breastfeeding, a multivariate regression model was used (Table 4). Duration of artificial feeding, number of abortions, degree of religiosity, family stability scale, maternal age and socioeconomics exerted a negative effect on the duration of breastfeeding. The higher the mean of these variables, the shorter the breastfeeding duration. A positive association was found between the duration of breastfeeding and artificial feeding and family stability, and negative associations were found with other variables.

\section{Discussion}

Our results showed that women of urban origin had a significantly higher mean duration of artificial feeding than those of Bedouin origin. Significant differences among women's age and breastfeeding duration for their

\begin{tabular}{|c|c|c|c|c|c|}
\hline Breastfeeding & $\begin{array}{c}\text { Maternal } \\
\text { age } \\
\text { (years) }\end{array}$ & $\mathbf{n}$ & Mean & SD & $\mathbf{P}$ \\
\hline Child 1 & $\begin{array}{c}\leq 30 \\
31-40 \\
\geq 41 \\
\text { Total }\end{array}$ & $\begin{array}{l}256 \\
181 \\
152 \\
589\end{array}$ & $\begin{array}{l}6.14 \\
5.55 \\
7.84 \\
6.40\end{array}$ & $\begin{array}{l}6.79 \\
5.67 \\
7.20 \\
6.63\end{array}$ & $<0.005$ \\
\hline Child 2 & $\begin{array}{c}\leq 30 \\
31-40 \\
\geq 41 \\
\text { Total }\end{array}$ & $\begin{array}{l}160 \\
179 \\
152 \\
491\end{array}$ & $\begin{array}{l}5.52 \\
5.68 \\
7.92 \\
6.32\end{array}$ & $\begin{array}{l}5.47 \\
6.05 \\
7.54 \\
6.46\end{array}$ & $<0.001$ \\
\hline Child 3 & $\begin{array}{c}\leq 30 \\
31-40 \\
\geq 41 \\
\text { Total }\end{array}$ & $\begin{array}{c}64 \\
144 \\
137 \\
345\end{array}$ & $\begin{array}{l}5.16 \\
6.01 \\
8.82 \\
6.97\end{array}$ & $\begin{array}{l}5.71 \\
5.76 \\
8.15 \\
6.96\end{array}$ & $<0.001$ \\
\hline Child 4 & $\begin{array}{c}\leq 30 \\
31-40 \\
\geq 41 \\
\text { Total }\end{array}$ & $\begin{array}{c}35 \\
108 \\
116 \\
259\end{array}$ & $\begin{array}{l}4.94 \\
6.17 \\
9.29 \\
7.40\end{array}$ & $\begin{array}{l}5.97 \\
6.82 \\
8.28 \\
7.59\end{array}$ & $<0.001$ \\
\hline
\end{tabular}

Results measured by analysis of variance. $S D=$ standard deviation 


\begin{tabular}{lcc}
\hline $\begin{array}{l}\text { Table } 3 \text { Correlation coefficients between breastfeeding and } \\
\text { artificial feeding and health, sociocultural, demographic and } \\
\text { psychological factors }\end{array}$ & Breastfeeding & $\begin{array}{c}\text { Artificial } \\
\text { feeding }\end{array}$ \\
\hline Variables & $-0.13^{* *}$ & 0.081 \\
Maternal education & $-0.11^{*}$ & -0.054 \\
Paternal Education & $-0.22^{* *}$ & $0.18^{* *}$ \\
Maternal occupation & $-0.17^{* *}$ & $0.20^{* *}$ \\
Years of marriage & $-0.011^{*}$ & -0.04 \\
Age at marriage & $0.12^{* *}$ & 0.06 \\
Number of children & $0.25^{* *}$ & $-0.18^{*}$ \\
Number of abortions & -0.03 & $0.16^{*}$ \\
Average year stopping breastfeeding & -0.02 & $0.10^{*}$ \\
General health scale & $0.10^{* *}$ & $-0.26^{* *}$ \\
Religiosity scale & $-0.13^{* *}$ & $0.12^{* *}$ \\
Family stability scale & $-0.19^{* *}$ & $0.10^{*}$ \\
Self-esteem scale & $0.17^{* *}$ & 0.07 \\
Emotional scale & $0.10^{*}$ & $-0.33^{* *}$ \\
Age & $-0.24^{* *}$ & $0.14^{* *}$ \\
Socioeconomics & & \\
${ }^{*} P<0.05$ & & \\
${ }^{* *} P<0.01$ & &
\end{tabular}

first four children were found. There was also a significant relationship between some sociocultural, demographic and psychological factors and breast- or bottle-feeding behaviour. Our data show how modernization plays an important role affecting women's health in general and breastfeeding practice in particular. The mean duration of breastfeeding among Kuwaiti mothers did not exceed six months. In contrast, artificial feeding lasted for around 20 months. Although the World Health Organization (WHO) strongly recommends exclusive breastfeeding up to six months of age, with continued breastfeeding along with appropriate complementary foods up to two years of age or beyond, there has been a decline in the duration of breastfeeding over time in Kuwait (16). Kuwaiti mothers, like $65 \%$ of those in Europe and the United States of America, do not follow the WHO recommendation (17). A new study in Kuwait showed that $30 \%$ of all infants received breast milk for up to 6 months (18). This affects women's general health (19). The proportion of children breastfeeding at six months in Kuwait is below international targets and ranges from 35 to $44 \%$.

Changes in women's roles in Kuwait constitute the strongest factor for explaining the decline in duration of breastfeeding. The number of women involved in the labour force has been increasing, especially in the last two decades, and has reached $42 \%$ of the total local labour force (20), with a greater percentage in higher education compared with men (21). Traditionally, women spent most of their time at home taking care of their children. With few responsibilities for women outside the home, the fertility rate was higher compared with that in modern
Table 4 Prediction of effect of social, psychological and demographic variables on duration of breastfeeding, a multivariate regression model

\begin{tabular}{lccc} 
Variables & B & $\beta$ & t \\
\hline Artificial feeding & 3.43 & 0.88 & $19.11^{* * *}$ \\
Abortion & -6.19 & -0.14 & $-2.84^{* *}$ \\
Religiosity & -4.75 & -0.12 & $-2.21^{*}$ \\
Family stability & 0.357 & 0.18 & $2.69^{*}$ \\
Maternal age & -0.721 & -0.12 & $-1.98^{*}$ \\
Socioeconomics & -4.06 & -0.15 & $-1.95^{*}$ \\
\hline$R 20.24$ & & & \\
$F=3.55^{* * *}$ & & & \\
Adjusted $R^{2} 0.18$ & & & \\
${ }^{*} P<0.05$ & & & \\
${ }^{* *} P<0.01$ & & & \\
${ }^{* * *} P<0.001$ & & &
\end{tabular}

society. Modernization has resulted in a clear decline in fertility rates in Kuwait (22). Work stress and time spent at work may be the main reasons for the reduction in duration of breastfeeding in Kuwait. Grummer-Strawn has shown that there is a universally downward trend in the duration of breastfeeding (23).

Our results show that older women have a longer duration of breastfeeding. This also may explain why the educational level of women is negatively related to the duration of breastfeeding. Other important elements related to modern life and women's age that may affect the duration of breastfeeding are years of marriage, age at marriage, number of children, socioeconomic status, and husband's educational level. These results are supported by previous studies (24).

Our data did not show a clear difference between Sunnis and Shiites for duration of breastfeeding and artificial feeding. Lack of any difference in breastfeeding behaviour among a population may indicate the effect of acculturation. Some studies have concentrated on acculturation among different ethnic groups and duration of breastfeeding (25). In modern Kuwait, all subgroups have become more connected to one other, as they are involved in the same social and economic activities. Acculturation in Kuwait has been facilitated by the small land mass, availability of communication technology, and equal opportunities for work and education for all Kuwaiti citizens.

We showed that women in a consanguineous marriage had a longer mean duration of breastfeeding than women in a nonconsanguineous marriage. Although there has been a decline in consanguinity (26) and the tendency for women to live in a nuclear family in Kuwait $(5,27,28)$, many still practice consanguinity. Kin provide family members and women with a high level of social support. One aspect of this is taking care of each other's children. A woman who marries her relative always lives in the extended family with support and help from family members. Relatives can offer a great deal of help with social life duties and responsibilities. 
Women in a consanguineous marriage have more time to take care of their children, especially when new born, compared with others who marry outside their families. This, in general, has a positive effect on women's health (29). Women from a Bedouin background used artificial feeding more than women of urban origin did. A possible explanation is that they have become involved in modern social life only recently, compared with others. Education is the main factor in this involvement. There was a boom of Kuwaiti women in higher education in recent decades and most of these women were of Bedouin origin $(5,21)$. The number of women attending university increased because of changes in traditional and tribal values concerning women's education and work. As a result, artificial feeding became an alternative method for them during this period of transition.

Other factors related to the duration of breastfeeding include religiosity and self-esteem. Some have stated that religiosity is the major factor that affects the duration of breastfeeding $(30,31)$. Self-esteem was a major psychological factor related to breastfeeding, which was also supported in previous studies (32). Religiosity and self-esteem are related to women's mental health. Mothers who are happy are healthier than others who are not, and this can affect breastfeeding $(29,33)$.

This study was primarily limited by its sample size and selection. It could be said that this was a primary study that examined too many variables related to breastfeeding. For this reason, further studies are needed with a larger sample of Kuwaiti women and examining different variables. Some social, demographic and psychological factors that affect breastfeeding practices also need to be studied independently. We also need some research using qualitative methods to support the purely quantitative techniques used in this study, especially for such a behavioural research aim. Factors such as education, nature of work, religiosity, and social family life need to be researched further in future studies. Biocultural studies are rare in Kuwait and more are needed.

\section{Conclusion}

Our data show that some social, psychological and demographic variables influence breastfeeding practice among mothers in Kuwait. Although there is no information in the literature to allow trend analysis of breastfeeding over time, our data clearly show the decline in breastfeeding duration. There is a trend toward western lifestyle. The reduced duration of breastfeeding is related to increased numbers of women going out to work, as in western countries. That was one of the major changes in the role of women that had an effect on health. Health promotion programmes for mothers are needed before and after birth. There is a need to limit inappropriate marketing of breast-milk substitutes, empower mothers to breastfeed during work time, and establish nurseries for mothers at work and prepare health awareness campaigns.

Funding: This research is funded by Research Department at Kuwait University (Project no. OSo1/11). Authors would like to thank Kuwait University for their support.

Competing interests: None declared.

\section{Variables sociales, psychologiques et démographiques associées à l'allaitement chez les mères koweïtiennes \\ Résumé}

Contexte : De nombreuses études ont déjà examiné les rapports entre l'allaitement au sein et certaines variables sociales, psychologiques et démographiques.

Objectifs: L'objectif de la présente étude était de déterminer l'impact des variables sociales, psychologiques et démographiques sur l'allaitement chez les mères koweïtiennes.

Méthodes : On a sélectionné 712 femmes mariées au total qui ont été priées de répondre à un questionnaire. Les questions portaient sur la durée de l'allaitement et de l'alimentation au biberon, le lien de parenté entre les époux, l'appartenance religieuse et le milieu. On a utilisé des échelles autorapportées de religiosité, de stabilité familiale et de santé générale.

Résultats : Les femmes issues de milieux urbains et vivant au sein d'un mariage consanguin ont fait état de durées d'allaitement moyennes plus longues que celles issues de racines bédouines et vivant dans un mariage non consanguin. Des différences significatives sur le plan de la durée d'allaitement entre les trois groupes d'âge maternels ont été notées. Un lien significatif a été constaté entre la durée de l'allaitement et toutes les variables sociales, psychologiques et démographiques, à l'exception de la santé générale. Des corrélations ont été établies entre la durée d'allaitement au sein et les niveaux d'éducation de la mère et du père, la profession de la mère, l'année du mariage, l'âge au moment du mariage, l'échelle de stabilité de la famille, l'échelle d'estime personnelle et les variables socio-économiques. La durée d'alimentation au biberon, le nombre d'avortements, le degré de religiosité, l'échelle de stabilité de la famille, l'âge et l'échelle socio-économique étaient liés à la durée de l'allaitement au sein par la mère.

Conclusions : L'éducation affecte de façon importante la santé des femmes en général et la pratique de l'allaitement au sein en particulier.. 


\section{المتغيرات الاجتحاعية و النفسية و السكانية المتعلقة بالرضاعة الطبيعية بين الأمهات في دولة الكويت}

يعقوب الكندري، رمضان عبد الستار أحمد

الخلاصة

المدف: الهلفية: ناقش الكثير من الدر اسات العلاقة بين الرضاعة الطبيعية وبعض المتغيرات الاجتماعية والنفسية والسكانية.

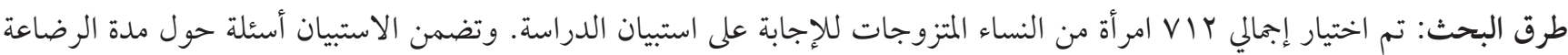

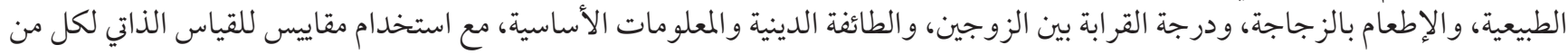
الالتزام الديني والاستقرار العائلي والحالة الصحية الصدية العامة.

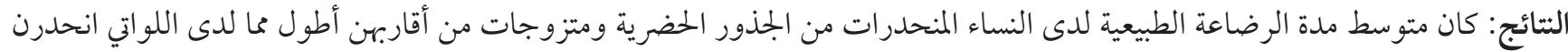

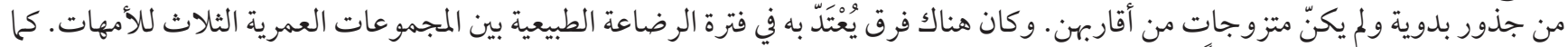

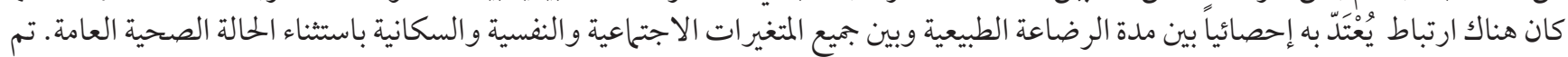

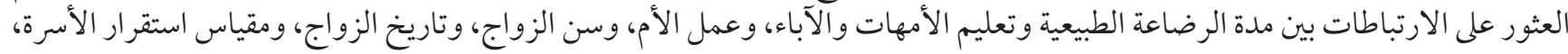

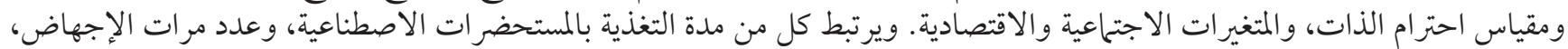

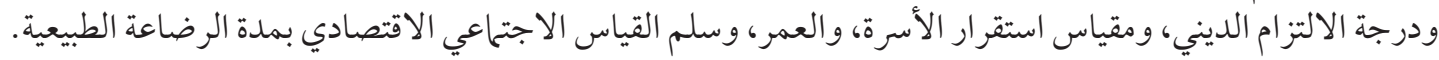
الاستنتاج: يؤدي التعليم دوراً هاماً في التأثير على صحة المر أة بشكل عام وعلى ممارسة الرضاعة الطبيعية على وجه الخصوص.

\section{References}

1. Al-Enezi F, Al-Kentar F. [A field study of feeding behavior in Kuwaiti society]. J Contemp Psychol Humanit. 2002;13:81-114 (in Arabic).

2. Ali, MA. [Child-rearing and personality: a comparative study of the Egyptian, Kuwait and Bahrain societies. First report on breastfeeding and weaning]. J Faculty Arts Educ. 1973(3-4):331-370 (in Arabic).

3. Amine EK, Al-Awadi F. Impact of mother's education on infant feeding pattern and weaning practices in Kuwait. Ecol Food Nutr. 1990;24(1):29-36. https://doi.org/10.1080/03670244.1990.9991117

4. Al Bustan M, Kohli BR. Socio-economic and demographic factors influencing breast-feeding among Kuwaiti women. Genus. 1988 Jan-Jun;44(1-2):265-78. PMID:12281668

5. Al-Kandari Y. [Change and modernization: Kuwaiti family as a model]. Cairo: Al-maktab Al-jame'ai Al-Hadeeth; 2010 (in Arabic).

6. Muktar HR. [Developing a measure of domestic instability in the Kuwaiti society]. Arab J Humanit. 1999;68(17):9-29 (in Arabic).

7. Thulier D, Mercer J. Variables associated with breastfeeding duration. J Obstet Gynecol Neonatal Nurs. 2009 May-Jun;38(3):25968. https://doi.org/10.1111/j.1552-6909.2009.01021.x PMID:19538614

8. Al-Kantar F, Buaufleas M. [Breastfeeding behavior among Syrian mothers: descriptive and analytical study]. J Arab Children. 2003;14:36-55 (in Arabic).

9. Buaufleas M. [Development of social interaction between mother and child in the feeding and weaning positions] [thesis]. University of Damascus; 2001 (in Arabic).

10. al-Ayed IH, Qureshi MI. Breastfeeding practices in urban Riyadh. J Trop Pediatr. 1998 Apr;44(2):113-7. https://doi.org/10.1093/ tropej/44.2.113 PMID:9604602

11. Al-Kandari Y. Social support and its relationship to hypertension and general health status among older adults in the Mobile Care Unit in Kuwait. J Cross Cult Gerontol. 2011;26(2):175-87. https://doi.org/10.1007/s10823-011-9139-9 PMID:21271283

12. Abdel-Khalek A. Happiness, health, and religiosity: significant relations. Ment Health Relig Cult. 2006;9(1):85-97. https://doi. org/10.1080/13694670500040625

13. Abdel-Khalek AM. Assessment of intrinsic religiosity with a single-item measure in a sample of Arab Muslims. J Muslim Ment Health. 2007;2(2):211-5. https://doi.org/10.1080/15564900701614874

14. Rosenberg M. Society and the adolescent self-image. Princeton (NJ): Princeton University Press; 1965.

15. Darweesh W, Shaker F. The effect of labor force participation on mental health conditions and physical working women: a comparative study between working and non-working in Oman. J Socl Sci.1999;37(2):113-54.

16. Exclusive breastfeeding. World Health Organization (http://www.who.int/nutrition/topics/exclusive_breastfeeding/en/, accessed 22 March 2018).

17. Fewtrell M. Weaning before six months 'may help breastfed babies'. BBC News. 14 January 2011 (http://www.bbc.com/news/ health-12180052, accessed 22 March 2018) 
18. Dashti M, Scott JA, Edwards CA, Al-Sughayer M. Determinants of breastfeeding initiation among mothers in Kuwait. Int Breastfeed J. 2010 Jul 28;5(1):7. https://doi.org/10.1186/1746-4358-5-7 PMID:20667112

19. Kennedy K. Effect of breastfeeding on women's health. Int J Gynaecol Obstet. 1994 Dec;47 Suppl:S11-20. PMID:7713302.

20. Jaleeli R. Woman and development in the Arabian countries: Kuwaiti women as a case. Kuwait: Arabic Planning Institution; 2008.

21. 21. Al-Kandari, Y. Fertility and its relation with sociocultural factors in Kuwaiti Society. East Mediterr Med J. Nov-Dec;13(6):136471. PMID:18341186

22. 22-Al- Kandari Y. Fertility and its relationship with sociocultural factors in Kuwaiti society. Eastern Medit Health J. 2007 NovDec;13(6):1364-71

23. Grummer-Strawn LM. The effect of changes in population characteristics on breastfeeding trends in fifteen developing countries. Int J Epidemiol. 1996 Feb;25(1):94-102. https://doi.org/10.1093/ije/25.1.94 PMID:8666510

24. Scott JA, Binns CW. Factors associated with the initiation and duration of breastfeeding: a review of the literature. Breastfeed Rev. 1999 Mar;7(1):5-16. PMID:10197366

25. Rassin DK, Markides KS, Baranowski T, Richardson CJ, Mikrut WD, Bee DE. Acculturation and the initiation of breastfeeding. J Clin Epidemiol. 1994 Jul;47(7):739-46. https://doi.org/10.1016/0895-4356(94)90171-6 PMID:7722587

26. Al-Kandari, Y. [Consanguinity in Kuwait and its relations to some sociocultural determinants]. Ann Arts Soc Sci. Kuwait University: Academic Publication Council. No. 252(26); 2006 (in Arabic).

27. Al-Kandari, Y and Poirier, Frank. Modernization and family structure in Kuwait. Educ J. 2001;15(60):225-39.

28. Al-Thakeb F. The Arab family and modernity: evidence from Kuwait. Curr Anthropol. 1985;26(5):575-80. https://doi. org/10.1086/203346

29. Groër MW. Differences between exclusive breastfeeders, formula-feeders, and controls: a study of stress, mood, and endocrine variables. Biol Res Nurs. 2005 Oct;7(2):106-17. https://doi.org/10.1177/1099800405280936 PMID:16267372

30. Forman MR. Review of research on the factors associated with choice and duration of infant feeding in less-developed countries. Pediatrics. 1984 Oct;74(4 Pt 2):667-94. PMID:6384918

31. Azaiza F, Palti H. Determinants of breastfeeding among rural Moslem women in Israel. Fam Syst Health. 1997 Summer;15(2):203-11. https://doi.org/10.1037/hoo89801 PMID:12321596

32. Baghurst P, Pincombe J, Peat B, Henderson A, Reddin E, Antoniou G. Breast feeding self-efficacy and other determinants of the duration of breast feeding in a cohort of first-time mothers in Adelaide, Australia. Midwifery. 2007 Dec;23(4):382-91. https://doi. org/10.1016/j.midw.2006.05.004 PMID:17126967

33. Mezzacappa ES, Katlin ES. Breast-feeding is associated with reduced perceived stress and negative mood in mothers. Health Psychol. 2002 Mar;21(2):187-93. https://doi.org/10.1037/0278-6133.21.2.187 PMID:11950109 